Jurnal Peternakan Indonesia, Oktober 2019

Vol. 21 (3): 257-265

ISSN 1907-1760 E-ISSN 2460-6626

DOI: $10.25077 /$ jpi.21.3.257-265.2019

Accredited: 14/E/KPT/2019

Available online at http://jpi.faterna.unand.ac.id/

\title{
Penggunaan Baglog Pelepah Sawit Fermentasi Jamur Pleurotus ostreatus untuk Pakan Ternak Kambing
}

\section{Utilization of Baglog Palm Fronds Fermented by Pleurotus ostreatus Fungi for Goats Feed}

\author{
P. Z. Jati ${ }^{1 *}$, Y. Metri ${ }^{2}$, R. Rianita ${ }^{1}$, L. Warly ${ }^{3}$, dan M. Zain ${ }^{3}$ \\ ${ }^{1}$ Program Studi S2 Ilmu Peternakan, Fakultas Peternakan, Universitas Andalas, Padang, 25163 \\ ${ }^{2}$ Program Studi S3 Ilmu Peternakan, Fakultas Peternakan, Universitas Andalas, Padang, 25163 \\ ${ }^{3}$ Program Studi Peternakan, Fakultas Peternakan, Universitas Andalas, Padang, 25163 \\ *E-mail: putrizuliajati01@gmail.com
}

(Diterima: 19 Juli 2019; Disetujui: 20 September 2019)

\begin{abstract}
ABSTRAK
Penelitian ini memiliki tujuan untuk melihat pengaruh pengunaan baglog pelepah sawit fermentasi dengan jamur (Pleoratus ostreatus) terhadap retensi N dan performa ternak kambing. Penelitian menggunakan metode Rancangan Acak Kelompok (RAK) terdiri dari 4 ulangan dan 4 perlakuan disetiap kombinasi. Perlakuan penelitian ini adalah: $A=0 \%$ Baglog, $B=20 \%$ Baglog, $C=30 \%$ Baglog, dan $D=40 \%$ Baglog. Variabel yang diamati konsumsi $\mathrm{BO}$, konsumsi $\mathrm{BK}$, $\mathrm{PBBh}$ dan retensi $\mathrm{N}$. Hasil analisis keragaman menunjukkan bahwa perlakuan $(\mathrm{P}>0,05)$ memberikan pengaruh tidak berbeda nyata terhadap komsumsi $\mathrm{BO}, \mathrm{BK}, \mathrm{PBBh}$ dan $(\mathrm{P}<0,01)$ memberikan pengaruh yang sangat nyata terhadap retensi $\mathrm{N}$. Dari hasil penelitian ini dapat disimpukan bahwa penggunaan baglog pelepah sawit yang difermentasi jamur (Pleorotus ostreatus) sampai dengan level $40 \%$ palatabel dikonsumsi ternak dengan hasil performan ternak dengan nilai konsumsi BK 1946,60 (g/ekor/h), BO 1455,96 (g/ekor/h) dan PBBh 136,25 (g/ekor/h), tetapi berpengaruh terhadap retensi $\mathrm{N}$ dengan nilai 6,34 (g/ekor/h).
\end{abstract}

Kata kunci: kambing, pelepah sawit, Pleurotus ostreatus, performans, retensi N

\section{ABSTRACT}

The aim of this study was to determine the effect of the utilization of fermented palm fronds with fungus (Pleoratus ostreatus) to $N$ retention and performance of goats. The study used a randomized block design (RBD) consisting of 4 replications and 4 treatments in each combination. The treatments of this research are: $A=0 \%$ Baglog, $B=4020 \%$ Baglog, $C=30 \%$ Baglog and $D=40 \%$ Baglog. The variables observed were dry matter (DM) and organic matter (OM), consumption, avarege daily gain $(A V G)$ and $N$ retention. Results of analysis of variance showed that the treatment $(P>0.05)$ had no significant effect on OM, DM consumption, $A V G$ and $(P<0.01)$ had a highly significant effect to $N$ retention. From these results, this study it can be concluded that the use of baglog palm fronds fermented mushroom (Pleorotus ostreatus) up to the level of $40 \%$ palatabel consumed by goats with performance results with DM and OM consumption were $1946.60 \mathrm{gram} /$ day/head and $1455.96 \mathrm{gram} /$ day/head. The AVG were $136.25 \mathrm{gram} /$ day/ head, but gave a significant effect on $N$ retention with a value of $6.34 \mathrm{gram} /$ day/head.

Keywords: goats, palm fronds, Pleurotus ostreatus, performance, $N$-retention

\section{PENDAHULUAN}

Kambing PE telah lama dipelihara, sehingga sudah dianggap kambing lokal dengan mutu genetik yang lebih baik dari kambing lokal lainnya (Pazla et al., 2018). Pemberian pakan yang seadanya disebabkan oleh harga pakan berkualitas baik relatif mahal, sehingga peternak tidak mampu mengeluarkan dana untuk pemberian pakan berkualitas baik. Salah satu limbah perkebunan yang cukup potensial untuk dijadikan pakan untuk ternak adalah pelepah kelapa sawit (Gunawan dan Thalib, 
2014). Ditinjau dari potensi pengembangan kelapa sawit, jumlah lu as areal perkebunan kelapa sawit di Sumatera Barat tahun 2014 diperkirakan $374.337 \mathrm{Ha}$ dengan jumlah produksi 956.286 ton (Dinas Perkebunan Sumatera Barat, 2014). Setiap pohon kelapa sawit dapat menghasilkan 22 pelepah/tahun dan rataan bobot pelepah per batang mencapai $2,2 \mathrm{~kg}$ (setelah dikupas untuk pakan) sehingga setiap hektar dapat menghasilkan pelepah segar untuk pakan sekitar 9 ton/ha/tahun atau setara dengan 1,64 ton/ha/tahun bahan kering (Dwiyanto et al., 2003). Pelepah kelapa sawit dapat dipergunakan sebagai sumber hijauan atau dapat diberikan dalam bentuk silase yang dikombinasikan dengan bahan lain atau konsentrat sebagai campuran (Mathius et al., 2004). Kandungan nutrisi pelepah sawit adalah protein kasar (PK) 3,44\%, lemak kasar (LK) 3,23\%, serat kasar (SK) 48,6\%, abu $9,37 \%$, NDF 71,90\%, ADF 43,36\%, dan lignin $17,4 \%$. Serat kasar merupakan komponen penyusun terbesar dari pelepah kelapa sawit, di mana komponen fraksi serat pelepah kelapa sawit terdiri dari selulosa, hemiselulosa, lignin dan silika (Elisabeth dan Ginting, 2003). Tingginya kadar lignin dalam pakan akan mengakibatkan rendahnya nilai gizi palatabilitas, dan daya cerna terhadap pakan (Rahayu et al., 2015), sehingga menurut Lynd and Zhang (2002) tidak dapat dimanfaatkan secara maksimal oleh ternak ruminansia. Untuk itu diperlukan teknologi untuk meningkatkan kualitas pakan baik itu nilai gizi dan kecernaan dari limbah tersebut.

Salah satu upaya untuk menurunkan kandungan lignin pada pelepah sawit adalah dengan proses delignifikasi yang dapat dilakukan dengan menggunakan perlakuan kimia atau secara biologi. Perlakuan biologi yang menggunakan mikroorganisme penghasil enzim menjadi salah satu alternatif yang banyak digunakan. Produk fermentasi limbah pelepah sawit yang dapat dihasilkan disebut baglog pelepah sawit. Baglog merupakan istilah lain dari media tanam jamur dengan penggantian bahan baku yang menggunakan media pelepah sawit yang telah dihaluskan sehingga limbah baglog pelepah sawit fermentasi tersebut yang akan digunakan untuk pakan ternak. Menurut Yuliastuti et al. (2003) diperkirakan setelah usai masa tanam, media tanam jamur tiram putih ini masih dapat dipergunakan sebagai bahan makanan ternak ruminansia. Pada saat sekarang ini belum banyak penelitian tentang pemanfaatan limbah media tanam jamur sebagai pakan ternak, padahal limbah tersebut mengandung komponen-komponen nutrisi yang bermanfaat bagi ternak. Limbah media jamur tiram putih (Pleurotus ostreatus) masih mengandung nutrisi yang dibutuhkan oleh ternak (Puspitasari, 2009). Mikroorganisme yang mampu mendegradasi lignin pada proses pelapukan kayu adalah Jamur pelapuk putih (JPP). Menurut Fitria (2008) jamur pelapuk putih (Pleoratus ostreatus) merupakan salah satu jenis JPP yang mampu merombak lignin. Kemampuan tersebut tidak terlepas dari peran enzim lignolitik yang dihasilkannya, yaitu lakase (Lac), mangan peroksidase (MnP) dan lignin peroksidase (LiP). Degradasi lignin melibatkan aktivitas enzim lignase yang dihasilkan oleh jamur pelapuk putih yaitu lignin peroksidase, manganese peroksidase dan laktase (Hendro et al., 2007). Oleh karena itu penggunaan baglog pelepah sawit ini dapat digunakan sebagai subtitusi hijauan dan memberi pengaruh retensi pakan dalam tubuh ternak. Dari uraian diatas maka dilakukan penelitian mengenai penggunaan terbaik level baglog pelepah sawit fermentasi (Pleoratus ostreatus) terhadap performans dan rentensi $\mathrm{N}$ ternak kambing.

\section{METODE}

\section{Materi}

Materi yang di gunakan pada penelitian ini adalah Pelepah kelapa sawit yang telah di coper dan untuk fermentasi menggunakan jamur pelapuk putih (Pleurotus ostreatus) dengan dosis 7\% dengan lama fermentasi 3 bulan menurut (Metri et al., 2018). Dengan komposisi baglog : Dalam $100 \mathrm{~kg}$ pelepah sawit, dedak $15-20 \%$, urea/kapur $2 \%$, gula

Penggunaan Baglog Pelepah Sawit ... (Jati et al.) 
Tabel 1. Kandungan zat-zat gizi bahan penyusun ransum

\begin{tabular}{|c|c|c|c|c|c|c|c|c|c|c|}
\hline \multirow{2}{*}{ No } & \multirow{2}{*}{ Bahan } & \multicolumn{9}{|c|}{ Kandungan zat-zat Makanan (\%) } \\
\hline & & BK & BO & PK & LK & SK & BETN & TDN & Lignin & $\mathrm{Abu}$ \\
\hline 1. & Ampas Tahu & 9,15 & 97,01 & 18,80 & 3,00 & 23,00 & 52,21 & 69,68 & 1,80 & 2,99 \\
\hline 2. & Dedak Halus & 91,02 & 86,03 & 6,26 & 1,00 & 26,00 & 52,77 & 55,30 & 3,84 & 13,97 \\
\hline 3. & Bungkil Kelapa & 90,55 & 97,01 & 10,18 & 10,00 & 15,00 & 61,83 & 78,35 & 0,89 & 2,99 \\
\hline 4. & Hijauan & 25,57 & 96,72 & 22,98 & 5,80 & 18,17 & 49,77 & 72,54 & 4,57 & 3,28 \\
\hline 5. & Baglog Pelepah Sawit & 46,27 & 77,00 & 16,45 & 1,00 & 29,00 & 30,55 & 45,71 & 17,54 & 23,00 \\
\hline
\end{tabular}

Sumber: Analisis Laboratorium Nutrisi Fakultas Peternakan Universitas Andalas Padang, 2017.

Tabel 2. Bahan penyusun ransum

\begin{tabular}{lrrrr}
\hline \multirow{2}{*}{ Bahan Penyusun Ransum (Nutrien) } & \multicolumn{4}{c}{ Formulasi Ransum Penelitian (\%) } \\
\cline { 2 - 5 } Ampas Tahu & $\mathrm{A}$ & $\mathrm{B}$ & $\mathrm{C}$ & $\mathrm{D}$ \\
\hline Dedak Halus & 30,0 & 30,0 & 30,0 & 30,0 \\
Bungkil Kelapa & 7,5 & 7,5 & 7,5 & 7,5 \\
Hijauan & 2,5 & 2,5 & 2,5 & 2,5 \\
Baglog Pelepah Sawit & 60,0 & 40,0 & 30,0 & 20,0 \\
\hline Total & 0,0 & 20,0 & 30,0 & 40,0 \\
\hline Kandungan Zat Makanan Ransum : & 100,0 & 100,0 & 100,0 & 100,0 \\
BK & & & & \\
BO & 27,18 & 31,32 & 33,39 & 35,46 \\
PK & 96,01 & 92,07 & 90,10 & 88,12 \\
LK & 20,15 & 18,85 & 18,19 & 17,54 \\
SK & 4,71 & 3,74 & 3,27 & 2,79 \\
Abu & 20,13 & 22,29 & 23,38 & 24,46 \\
BETN & 3,99 & 7,93 & 9,90 & 11,88 \\
Lignin & 51,03 & 47,18 & 45,26 & 43,34 \\
\hline
\end{tabular}

$1 \%$, air $50-60 \%$ Peralatan yang digunakan dalam penelitian ini adalah baglog ring, hand sprayer, selang, plastik, timbangan analitik, saringan, mesin coper pelepah sawit serta Kumbung jamur.

\section{Ransum Penelitian}

Ransum penelitian disusun berdasarkan kebutuhan bahan kering yaitu 2,5\% dari Bobot badan. Penggunaan antara konsentrat dan hijauan adalah $40: 60$. Hijauan terdiri baglog pelepah sawit yang difermentasi dan hijauan. Dari 60\% campuran baglog pelepah sawit dan hijauan di kombinasikan sesuai level perlakuan. Dengan komposisi penyusun ransum dapat dilihat pada Tabel 1. dan formulasi ransum dapat dilihat pada Tabel 2. Persentase komposisi ransum penelitian dapat dilihat pada Tabel 2.

\section{Rancangan Percobaan}

Penelitian menggunakan metode Rancangan Acak Kelompok (RAK) terdiri dari 4 ulangan dan 4 perlakuan disetiap kombinasi. Perlakuan penelitian ini adalah: A $=0 \%$ Baglog, $\mathrm{B}=20 \%$ Baglog, $\mathrm{C}=30 \%$ Baglog, dan D $=40 \%$ Baglog. 
Data di analisis menggunakan analisis ragam (ANOVA) menurut Steel and Torrie (1992). Bila hasil analisis ragam menunjukkan pengaruh nyata maka dilakukan uji lanjut dengan Duncan's Multiple Range Test (DMRT).

\section{Ternak percobaan}

Ternak yang digunakan dalam penelitian ini adalah kambing peranakan ettawa (PE) jantan sebanyak 16 ekor dengan berat badan 40-60 Kg. Kandang yang digunakan saat melakukan percobaan adalah kandang metabolik individual yang merupakan kandang panggung dengan ukuran masing-masing $1,5 \times 2$ meter dilengkapi dengan tempat makan dan tempat minum. Lantai kandang berjarak \pm 1 meter dari tanah.

\section{Pelaksanaan Penelitian}

Persiapan Kandang dan Ternak. Sebelum percobaan dimulai, kandang dibersihkan dan disucihamakan dengan desinfektan. Ternak yang akan digunakan diperiksa kesehatannya dan diberi obat cacing. Pelaksanaan dikandang dilakukan tiga periode yaitu:

1. Periode Adaptasi. Periode ini bertujuan untuk menyesuiakan ternak dengan ransum perlakuan dan lingkungan percobaan. Pada periode ini ransum yang diberikan adalah bahan-bahan yang akan dipakai untuk penyusunan ransum perlakuan dan diberikan dengan jumlah terbatas (Pada akhir periode ini dilakukan penimbangan bobot badan awal). Periode ini berlangsung selama 1 bulan.

2. Periode Pendahuluan. Periode ini berlangsung selama 15 hari. Pada periode ini sudah diberikan ransum perlakuan. Penimbangan bobot badan dilakukan pada akhir periode pendahuluan dan dilakukan pencatatan jumlah ransum yang dikonsumsi sudah dilakukan.

3. Periode collecting. Lama periode ini adalah 5 hari. Pada periode ini masih dilakukan pencatatan jumlah ransum yang dikonsumsi. Pengambilan sampel feses dan urin dilakukan setiap hari (selama 5 hari), serta pada akhir periode koleksi dilakukan penimbangan bobot badan akhir.

\section{Peubah yang diamati}

1. Konsumsi $\mathrm{BK}=[$ pemberian $(\mathrm{g}) \times \mathrm{BK}$ pemberian ] - [sisa (g) x \% BK sisa]

2. Konsumsi $\mathrm{BO}=[$ Pemberian $\mathrm{BK}(\mathrm{g}) \mathrm{x}$ $\% \mathrm{BO}$ pemberian] - [sisa BK (g) $\mathrm{x} \% \mathrm{BO}$ sisa]

3. Pengukuran neraca nitrogen (McDonald et al., 2002). Neraca nitrogen dihitung dengan cara: Perhitungan Retensi $\mathrm{N}$ $($ gram $)=(\mathrm{N}$ Konsumsi $-(\mathrm{N}$ Urin $+\mathrm{N}$ Feses))

$\mathrm{N}$ Konsumsi $=\frac{\text { PK Ransum Konsumsi }(\mathrm{g})}{6,25}$

$\mathrm{N}$ Urin $=\frac{\mathrm{N} \text { Urin }(\mathrm{g}) \mathrm{x} \text { Total Urin }(\mathrm{g})}{100}$

$\mathrm{N}$ Feses $=\frac{\text { PK Ransum Konsumsi }(\mathrm{g})}{6,25}$

4. Pertambahan Bobot Badan Harian (gram/ekor/hari). Pertambahan bobot badan harian dihitung dengan membagi pertambahan bobot badan selama pemeliharaan dalam satuan kilogram dengan lama pemeliharaan dalam satuan hari.

\section{HASIL DAN PEMBAHASAN}

\section{Konsumsi BK dan BO}

Konsumsi ransum perlakuan kambing PE yang diberi perlakuan baglog dapat dilihat pada Tabel 3. Berdasarkan hasil analisis sidik ragam didapatkan bahwa perlakuan memberikan pengaruh tidak nyata $(\mathrm{P}>0,05)$ terhadap konsumsi Bahan Kering (BK). Rataan konsumsi BK ransum ternak kambing yang diperoleh nilai rataan 1786,17$2066,178 \mathrm{~g} / \mathrm{ekor} / \mathrm{h}$. Tidak Berbeda nyatanya setiap perlakuan disebabkan oleh kemampuan ternak dalam mengkonsumsi ransum baik perlakuan A, B, C dan D ini relatif sama. Secara umum konsumsi BK dari hasil penelitian ini menunjukkan bahwa ransum 
Tabel 3. Rataan pengaruh perlakuaan baglog pelepah sawit fermentasi dengan jamur pelapuk putih (Pleoratus ostreatus) terhadap KBK, KBO dan $\mathrm{PBBh}(\mathrm{g} / \mathrm{ekor} / \mathrm{h})$

\begin{tabular}{lccc}
\hline \multirow{2}{*}{ Perlakuan } & \multicolumn{3}{c}{ Parameter (g/ekor/h) } \\
\cline { 2 - 4 } & KBK & KBO & PBBh \\
\hline A (Kontrol) & 1786,17 & 1636,25 & 147,50 \\
B (20\%) & 2066,17 & 1785,62 & 146,25 \\
C (30\%) & 1967,67 & 1571,6 & 145,63 \\
D (40\%) & 1946,60 & 1455,96 & 136,25 \\
\hline SE & 3,75 & 9,99 & 5,16 \\
\hline
\end{tabular}

Keterangan: Berbeda tidak nyata $(\mathrm{P}>0,05), \mathrm{SE}=$ Standar Error dari rata-rata, $\mathrm{KBK}=$ Konsumsi Bahan Kering, $\mathrm{KBO}=$ Konsumsi Bahan Organik, $\mathrm{PBBh}=$ Pertambahan Bobot Badan harian.

yang diberikan masih cukup palatabel bagi ternak kambing PE. Hal ini disebabkan karena penurunan kadar lignin dengan hasil analisa awal kandungan lignin pelepah sawit adalah $22,936 \%$ dan mengalami penurunan sampai bulan ke 3 menjadi $17,458 \%$ pada baglog pelepah sawit jamur pelapuk putih jenis Pleurotus ostreatus sudah memanfaatkan lignin untuk pertumbuhan jamur Pleurotus ostreatus. Ditambahkan oleh Fitria (2008) yang menyatakan bahwa JPP merupakan kelompok mikroorganisme yang memiliki kemampuan memecah lignin secara ekstensif menjadi karbondioksida dan air. Menurut Hadar et al. (1993) Jamur pelapuk putih (Pleoratus ostreatus) merupakan salah satu jenis JPP yang mampu merombak lignin. Ditambahkan Metri et al. (2018) bahwa baglog pelepah sawit fermentasi memberikan hasil terbaik pada dosis P. ostreatus 7\% dan lama inkubasi 3 bulan dengan lignin terbaik $7,24 \%$. Didukung pernyataan Febrina et al. (2014) menambahakan didalam rumen bahan pakan akan disimpan, zat-zat makanannya akan disederhanakan dan difermentasi.

Rataan konsumsi BK pada perlakuan A menunjukan nilai lebih rendah dibandingkan perlakuan $\mathrm{B}, \mathrm{C}$ dan $\mathrm{D}$ namun mengalami penurunan. Penurunan konsumsi BK terjadi dikarenakan oleh bertambahnya level baglog pelepah sawit yang diberikan ke ternak Kambing PE dalam ransum perlakuan. Diindikasikan bahwa baglog pelepah sawit memiliki sifat amba (bulky) yang menyebabkan peningkatan volume persatuan berat, sehingga laju pengosongan perut menjadi rendah. Bahan pakan yang cepat memenuhi ruang rumen sehingga ternak menjadi kenyang. Seiring dengan pendapat Chesworth (1992) menyatakan kandungan serat kasar yang tinggi menyebabkan mengurangi konsumsi ternak, karena membutuhkan waktu yang lebih lama untuk mencapai ukuran proporsional untuk meninggalkan rumen.

$$
\text { Rendahnya laju pengosongan }
$$
perut mengakibatkan kambing enggan mengkonsumsi ransum sehingga terbatasnya kapasitas rumen menampung ransum sehingga terjadi penurunan konsumsi BK. Dimana sifat fisik dari baglog pelepah sawit memiliki serat kasar yang tinggi (Tabel 2). Murni et al. (2008) menambahkan bahwa faktor pembatas utama pemanfaatan pelepah sawit yaitu rendahny a protein kasar berkisar 2,11 \% dan tingginya kandungan serat kasar mencapai 46,75 \% yang menyebabkan konsumsi dan palatabilitas menurun pula. Hal ini sesuai dengan pendapat Kamalidin et al. (2012) bahwa perbedaan jenis dan bentuk bahan pakan yang menyusun ransum dapat menimbulkan perbedaan tingkat palatabilitas yang pada akhirnya menyebabkan perbedaan jumlah pakan yang dikonsumsi oleh ternak. Ditambahkan oleh Anggorodi (1994) bahwa palatabilitas pakan secara kualitatif dipengaruhi oleh sifat fisik pakan yang meliputi bentuk, bau, rasa dan tekstur. Hasil penelitian ini mendapatkan rataan lebih tinggi dari hasil penelitian Arief 
(2018) yang mendapatkan konsumsi BK kambing PE laktasi dari ransum berbasis konsentrat limbah pelepah sawit $1,08-1,10$ $\mathrm{Kg} / \mathrm{ekor} / \mathrm{h}$ dan menujukkan lebih rendah dari penelitian Rizqan (2018) yang menggunakan ransum titonia dan limbah industri kelapa sawit dengan rataan konsumsi BK sebesar $3,41 \mathrm{Kg} / \mathrm{ekor} / \mathrm{h}$.

Pola konsumsi BO mengikuti pola konsumsi BK dan mempunyai korelasi positif. Hal ini disebabkan zat-zat yang terkandung dalam BO merupakan bagian dari BK. Semakin meningkat konsumsi BK, maka konsumsi BO juga meningkat (Tabel 3) dan sebaliknya seperti yang dilaporkan Febrina et al. (2014); Kamalidin et al. (2012). Rataan konsumsi BO selama penelitian berturut-turut dengan rataan 1455,96-1785,62 (g/ekor/h), konsumsi BO perlakuan menunjukkan tidak berbeda nyata $(\mathrm{P}>0.05)$. Nilai rataan tertinggi terdapat pada perlakuan B $(1785,62 \mathrm{~g} / \mathrm{ekor} / \mathrm{h})$ dan yang terendah pada perlakuan D $(1455,96 \mathrm{~g} / \mathrm{ekor} / \mathrm{h})$ penurunan konsumsi BO diindikasikan karena pengaruh bahan penyusun ransum perlakuan yang seiiring dengan penambahan baglog pada penyusun ransum sehingga konsumsi BO yang rendah disebabkan konsumsi BK yang rendah pula. Nilai ini lebih rendah dari penelitian (Pazla, 2018) yakni dengan nilai rataan konsumsi BO berkisar antara 2,32-2,67 $\mathrm{kg} / \mathrm{e} / \mathrm{h}$ yang memanfaatan pelepah Sawit dan Titonia (Tithonia diversifolia) dalam Ransum Kambing PE.

\section{Pertambahan Bobot Badan harian}

Hasil analisis statistik menunjukkan bahwa perlakuan memberikan pengaruh tidak nyata $(\mathrm{P}>0,05)$ terhadap pertambahan bobot badan harian $(\mathrm{PBBh})$. Hasil penelitian tersebut menunjukkan bahwa konsumsi yang relatif sama, sehingga tidak berpengaruh terhadap PBBh dengan rataan PBBh berkisar antara 136,25-147,50 (g/ekor/h), dimana perlakuan $\mathrm{A}, \mathrm{B}, \mathrm{C}$ dan D mengalami penurunan seiring dengan penurunan konsumsi BK (Tabel 3.). Tidak berbeda nyatanya perlakuan terhadap pertambahan bobot badan harian yang seiring dengan efisiensi penggunaan ransum yang menurun dengan kisaran rataan $6,60 \%$ -
8,34\%. sehingga dapat diasumsikan bahwa tidak adanya efek negatif pada PBBh. Tidak berbeda nyatanya setiap perlakuan juga mengindikasikan bahwa pakan baglog pelepah sawit fermentasi mampu mensubtitusi pakan hijauan. Pertambahan bobotbadan adalah salah satu gambaran kualitas pakan yang diberikan kepada ternak. Nurasih (2005) menyatakan pertambahan bobot badan sangat dipengaruhi oleh kualitas dan kuantitas pakan, hal ini yang dimaksud adalah penilaian pertambahan bobot badan ternak sebanding dengan ransum yang dikonsumsi. Pertambahan bobot hidup terjadi apabila ternak mampu mengubah zatzat pakan yang diperoleh menjadi produk ternak seperti lemak dan daging, setelah kebutuhan pokok terpenuhi. Rata-rata PBB harian berkisar antara 145,22-152,02 (g/ ekor/h) lebih tinggi dari penelitian Purbowati et al. (2008) dengan perlakuan pemanfaatan energi dari pakan komplit berkadar proteinenergi berbeda pada domba lokal jantan yang digemukkan secara feedlot.

\section{Neraca Keseimbangan Nitrogen}

Pemberian ransum perlakuan yang berbeda memberikan pengaruh sangat nyata $(\mathrm{P}<0,01)$ terhadap retensi $\mathrm{N}$ pada kambing PE. Uji Lanjut didapatkan bahwa retensi $\mathrm{N}$ pada perlakuan $\mathrm{C}$ dan $\mathrm{D}$ berbeda sangat nyata $(\mathrm{P}<0,01)$ lebih rendah terhadap perlakuan A dan tidak berbeda nyata $(\mathrm{P}>0,05)$ pada perlakuan $\mathrm{B}$, sedangkan retensi $\mathrm{N}$ perlakuan ransum A dan $\mathrm{B}$ tidak berbeda nyata $(\mathrm{P}>0,05)$. Retensi $\mathrm{N}$ menurun seiring dengan meningkatnya perlakuan penambahan level baglog pelepah sawit fermentasi dan jumlah kandungan protein pakan kambing (Tabel 2). Pengaruh level pemberian baglog pelepah sawit fermentasi dalam pakan terhadap retensi nitrogen disajikan pada Tabel 4. Rataan retensi nitrogen adalah 10,08, 9,91, 7,74 dan 6,34 (g/ ekor/hari). Keadaan ini terjadi terkait dengan kecernaan bahan kering pakan dan komposisi nutrien pakan yang diberikan. Secara statistik rataan retensi nitrogen cenderung menurun dengan meningkatnya level pemberian baglog pelepah sawit fermentasi dalam pakan. Retensi nitrogen pada perlakuan A

Penggunaan Baglog Pelepah Sawit ... (Jati et al.) 
Tabel 4. Neraca Keseimbangan Nitrogen Perlakuaan Baglog Pelepah Sawit Fermentasi dengan jamur pelapuk putih (Pleoratus ostreatus) (g/ekor/h)

\begin{tabular}{lccccc}
\hline \multirow{2}{*}{ Perlakuan } & \multicolumn{4}{c}{ Parameter (g/ekor/h) } & \multirow{2}{*}{ SE } \\
\cline { 2 - 5 } & Konsumsi N & N dalam Feses & N dalam Urin & Retensi N & \\
\hline A (Kontrol) & 34,10 & 12,21 & 11,81 & $10,08^{\mathrm{a}}$ & 3,82 \\
B (20\%) & 31,24 & 10,81 & 11,24 & $9,19^{\mathrm{ab}}$ & 1,37 \\
C (30\%) & 27,25 & 10,48 & 9,03 & $7,74^{\text {bc }}$ & 1,21 \\
D (40\%) & 25,68 & 8,87 & 10,48 & $6,34^{\mathrm{c}}$ & 0,31 \\
\hline
\end{tabular}

Keterangan: Superskrip yang berbeda pada kolom yang sama menunjukkan perbedaan sangat nyata $(\mathrm{P}<0,01)$ dan $\mathrm{SE}=$ merupakan standar error dari rata-rata.

lebih besar dibandingkan dengan $\mathrm{B}, \mathrm{C}$ dan D. Hal ini terjadi diduga karena kandungan protein kasar yang terdapat pada ransum perlakuan sebagian besar tidak mengalami perombakan di dalam rumen dan lolos masuk ke dalam usus. Hanya sebagian kecil yang dapat didegradasi dan dirombak oleh enzim proteolitik yang diproduksi oleh mikroba rumen menjadi oligopeptida dan selanjutnya menjadi asam amino. Oleh karena mikroba rumen tidak mempunyai sistem transpor untuk mengangkut asam amino ke dalam tubuhnya, maka asam amino tersebut akan dirombak menjadi amonia yang merupakan sumber nitrogen mikroba. Hal ini mengindikasikan bahwa nitrogen tersebut banyak terbuang pada feses dan urin. Nitrogen yang keluar melalui feses meliputi nitrogen pakan yang tidak tercerna dan nitrogen endogenous, sedangkan nitrogen yang keluar melalui urin menggambarkan bahwa banyaknya urea terbuang sebagai akibat $\mathrm{NH}_{3}$ menjadi tinggi yang merupakan hasil degradasi protein di dalam rumen yang tidak dimanfaatkan untuk sintesis protein oleh mikroba rumen (Puastuti et al., 2006).

Penurunan nilai retensi $\mathrm{N}$ ini dikarenakn semakin rendah pula konsumsi $\mathrm{N}$ ransum (Tabel 4), maka retensi nitrogen akan semakin turun pula. Jadi, retensi nitrogen merupakan selisih dari konsumsi nitrogen dengan ekskresi nitrogen melalui urin dan feses (Maynard and Loosli, 1969). Sehingga meningkatnya konsumsi ransum akan memberikan kesempatan kepada tubuh untuk meretensi lebih banyak makanan sehingga kebutuhan protein untuk pertumbuhan terpenuhi pula. Nitrogen dalam keadaan seimbang apabila jumlah $\mathrm{N}$ dikonsumsi sama dengan jumlah $\mathrm{N}$ yang diekskresikan. Retensi $\mathrm{N}$ negatif menunjukkan bahwa $\mathrm{N}$ yang diekskresikan lebih banyak daripada $\mathrm{N}$ yang dikonsumsi, sedangkan apabila jumlah $\mathrm{N}$ yang dikonsumsi lebih banyak daripada jumlah $\mathrm{N}$ yang diekskresikan maka akan terjadi Retensi $\mathrm{N}$ yang positif (Mc. Donald et al., 2002). Pakan yang di konsumsi oleh ternak ruminansia akan digunakan untuk memenuhi kebutuhan energi dan protein. Hasil penelitian ini menunjukkan nilai lebih tinggi dibandingkan hasil penelitian dengan nilai berkisar 1,17-3,32 (g/e/h) dengan perlakuan pemberian ransum rumput lapang dan kaliandra (Calliandra calothyrsus) pada ternak kambing kacang (Aeotpah et al., 2010). Angka ini relatif sama dengan retensi nitrogen perlakuan pakan pada penelitian pengaruh taraf kulit buah markisa (Passiflora edulis sims f. edulis deg) sebagai campuran pakan kambing kacang yaitu masing-masing 8,46 dan 8,42 g ekor-1 hari-1 (Kiston et al., 2006).

\section{KESIMPULAN}

Dari hasil penelitian ini dapat disimpukan bahwa penggunaan baglog pelepah sawit yang difermentasi jamur pelapuk putih (Pleorotus ostreatus) sampai dengan level $40 \%$ palatabel dikonsumsi ternak dengan hasil performan ternak. 


\section{DAFTAR PUSTAKA}

Anggorodi, R. 1994. Ilmu Makanan Ternak Umum. PT Gramedia. Jakarta.

Arief., Elihasridas., S. Somen., E. Roza., R. Pazla, and Rizqan. 2018. Production and Quality of Etawa Raw Milk Using Palm Oil Industry Waste and Paitan Plants as an Early Feed. Pak. J. Nutr., 17: 399-404.

Chesworth J. 1992. Ruminant Nutrition. London: MacMillan. P: 88-100.

Dinas Perkebunan Sumatera Barat. 2014. www.dinasperkebunanpelepahsawit sumaterabarat2014.go.id (Diakses pada tanggal 12 Maret 2018 Pukul 21.00 WIB).

Dwiyanto, K., D. Sitompul., I. Marti., I. W. Mathius, dan Soentoro. 2003. Pengkajian Pengembangan Usaha Sistem Integrasi Kelapa SawitSapi. Prosiding Lokakarya Nasional Sistem Integrasi Kelapa Sawit - Sapi. Bengkulu, 9-10 September 2003. Puslitbang Peternakan, Bogor. hlm. 1-22.

Elisabeth, J. dan S. P. Ginting. 2003. Pemanfaatan hasil samping industri kelapa sawit sebagai bahan pakan ternak sapi potong. Prosiding Lokakarya Sistem Integrasi Kelapa Sawit-Sapi. Bengkulu. 9-10 September 2003. Departemen Pertanian Bekerjasama dengan Pemerin tah Provinsi Bengkulu dan PT. Agricinal.

Febrina, D., N. Jamarun, dan M. Zain. 2014. Biological delignification by Phanerochaete chrysosporium with addition of mineral $\mathrm{Mn}$ and its effect on nutrient content of oil palm frond. Journal The 16th AAAP Animal Science Congress. Vol. 10-14.

Febrina, D., N. Jamarun., M.Zain, and Khasrad. 2017. Effects of Using Different Levels of Oil Palm Fronds (FOPFS) Fermented with Phanerochaete chrysosporium Plus Minerals (P, S, and Mg) Instead of
Napier Grass on Nutrient Consumption and the Growth Performance of Goats. Pak. J. Nutr., 16: 612-617.

Fitria, 2008. Pengolahan biomassa berlignoselulosa secara enzimatis dalam pembuatan pulp: studi kepustakaan. Jurnal Teknologi Pertanian Vol. 9 No.2.

Gunawan dan Talib, C. 2014. Potensi Pengembangan Bioindustri Dalam Sistem Integrasi Sapi Sawit. WARTAZOA Vol. 24 No. 2 Th. 2014 Hlm. 67-74.

Hadar, Y., Z. Kerem, and B. Gorodecki. 1993. Biodegradation of Lignocellulosic Agricultural Wastes by Pleurotus ostreatus. Journal of Biotechnology, 30: 133-139.

Hendro., R. Tjandra, dan S. Sri. H. S. 2007. Pemilihan Spesies Jamur dan Media Imobilisasi untuk Produksi enzim Lignolitik. ITB. Bandung.

Kamalidin., A. Agus., I. G. Suparta, dan B. Satria. 2012. Performa Domba yang Diberi Complete Feed Kulit Buah Kakao Terfermentasi. Jurnal Buletin Peternakan. 3(3):162-168.

Kiston., S. Komang., G. Wiryawan, dan Simon, P. G. 2006. Pengaruh Taraf Kulit Buah Markisa (Passiflora edulis Sims f. edulis Deg) sebagai Campuran Pakan Kambing Kacang: I. Konsumsi, Kecernaan dan Retensi Nitrogen. Jurnal. JITV Vol. 11 No. 2.

Laboratorioum Nutrisi Ruminansia. 2017. Fakultas Peternakan Universitas Andalas, Padang.

Lynd, L. R. and Y. Zhang. 2002. Quantitative determination of cellulase concentration as distinct from cell concentration in studies of microbial cellulose utilization: analytical framework and methodological approach.Biotechnol. Bioeng. 77:467-475.

Mathius, I. W., Azmi, B. P., Manurung, D. M., Sitompul, dan E. Prayatomo. 2004. Integrasi Sawit-Sapi: Imbangan 
pemanfaatan produk samping sebagai bahan dasar pakan. Prosiding. Sistem Integrasi Tanaman-Ternak. Denpasar Juli 2004. Hlm. 439-446.

Maynard, L. A. and J. K. Loosli. 1969. Animal Nutrition. 4th Edition. Mc Graw-Hill Book Co. Inc., New York.

McDonald, P. R.A., Edwards, and Greenhalgh, J. F. D. 2002. Animal Nutrition 6nd Ed. Longman Scientific and Technical, John Willey and Sons Inc. NewYork. P: 90-95.

Metri, Y., Warly, L. and Suyitman. 2018. Biodegradation of lignin by white-rot fungi (Pleurotus ostreatus) to decrease the fiber components in the palm midrib. Pakistan Journal of Nutrition. Vol. 17 No. 2: 71 - 75.

Murni., R. Suparjo., Akmal, dan B. L. Ginting. 2008. Buku Ajar Teknologi Pemanfaatan Limbah untuk Pakan. Laboratorium Makanan Ternak. Fakultas Peternakan universitas Jambi.

Nurasih, E. 2005. Kecernaan Zat Makanan dan Efisiensi Pakan pada Kambing Peranakan Ettawa yang Mendapat Ransum dengan Sumber Serat Berbeda. Skripsi. Bogor: Fakultas Peternakan. Institut Pertanian Bogor.

Pazla, R., Zain, M., Ryanto, H. I. and Dona, A. 2018. Supplementation of Minerals (Phosphorus and Sulfur) and Saccharomyces cerevisiae in a Sheep Diet Based on a Cocoa By-product. Pakistan Journal of Nutrition Volume 17, Number 7, 329-335.

Puastuti, W., D. Yulistiani, dan I. W. Mathius. 2006. Bungkil kedelai terproteksi cairan batang pisang sebagai pakan imbuhan ternak domba: In sacco dan in vivo. JITV 11: 106-115.

Purbowati, E., Sutrisno, C. I., Baliarti, E., Budhi, S. P. S. dan Lestariana, W. 2008. Pemanfaatan energi pakan komplit berkadar protein-energi berbeda pada domba lokal jantan yang digemukkan secara feedlot. J. Pengembangan Peternakan Tropis. Vol. 33. (10). 59-65.

Puspitasari, 2009. Pengaruh Level Penggunaan Limbah Media Tanam Jamur Tiram (Pleurotus ostreatus) Sebagai Sumber Serat Di Dalam Pakan Lengkap Terhadap Kecernaan Secara In Vitro. Universitas Brawijaya. Malang.

Rahayu, S., N. Jamarun., M. Zain, dan D. Febrina. 2015. Pengaruh Pemberian Dosis Mineral Ca dan Lama Fermentasi Pelepah Sawit terhadap Kandungan Lignin, Kecernaan BK, BO, PK dan Fraksi Serat (NDF, ADF, Hemiselulosa dan Selulosa) menggunakan Kapang Phanerochaete chrysosporium. Jurnal Peternakan Indonesia. Vol. 17 (2) ISSN 1907-1760.

Rizqan. 2018. Produksi dan Kualitas Susu Kambing Peranakan Etawa dengan Memanfaatkan Limbah Industri Kelapa Sawit dan Tanaman paitan Sebagai Pakan Ternak. [Tesis]. Padang. Program Pascasarjana Fakultas Peternakan Universitas Andalas.

Steel dan Torrie. 1992. Prinsip dan Prosedur Satistik. Jakarta. Gramedia Jakarta Utara. Yogyakarta.

Yuliastuti., Eko, E. S. dan Susilo, A. 2003. Studi Kandungan Nutrisi Limbah Media Tanam jamur Tiram Putih (Pleurotus ostreatus) Untuk Pakan Ternak Ruminansia. Jurnal Matematika, Saint, dan Teknologi. Vol. 4 (1): 54-61. 